\title{
STUDIES IN SO-CALLED WATER INTOXICATION
}

\author{
By FRANCIS SCOTT SMYTH, WILLIAM CALLAHAN DEAMER \\ AND NILKANTH M. PHATAK 1
}

(From the Department of Pediatrics and the George Williams Hooper Foundation for Medical Research, University of California Medical School, San Francisco)

(Received for publication July 20, 1932)

\section{INTRODUCTION}

Water retention and hydremia have attracted considerable attention in the last decade. In 1921 Miller and Williams (1) reported observations on three patients with hypertension and nephritis who were given 5 to 10 liters of water in 24 hours by Rehfuss tube. Two of these patients developed headache, dizziness, general depression, increased blood pressure and cramps in the legs. The third patient developed no such symptoms presumably because of extremely rapid elimination of water by the kidneys.

The following year (1922) Weir, Larson and Rowntree (2) reported observations on patients with diabetes insipidus. In these patients urination had been suppressed with pituitary extract while they continued to take their customary large amounts of fluid. Headache, nausea and vomiting resulted. Further observations were carried out on animals. Asthenia, salivation, vomiting, tremor, muscular twitching, ataxia, convulsions, coma and death occurred when large amounts of distilled water were given by stomach tube, both with and without pituitary injections. Dilution of the blood could not be demonstrated in either the patients with diabetes insipidus or in the experimental animals. The total nitrogen and chloride content of the plasma usually decreased slightly after the onset of symptoms. These investigators failed to find an explanation of the symptoms in edema of the brain, increase in blood volume or significant blood pressure change.

Rowntree (3) continued the investigation and in 1923 reported that the syndrome of water intoxication had been produced in dogs, cats, rabbits and guinea pigs. He found that intravenous salt solution prevented as well as cured the syndrome, which could not be produced by rectal administration of water or by an equal amount of normal saline given orally. An increased intracranial pressure was demonstrated in one animal at the time symptoms developed and a subsequent autopsy showed what was considered to be "increase of fluid within the brain substance." Rowntree concluded that "water intoxication is accompanied by, and is probably due to, increased intracranial pressure; this in turn is probably a manifestation of disturbance in the water-salt equilibrium of the central nervous system."

About the same time Moss (4) in England described the loss of large amounts of chloride in colliers by sweating. The miner's cramp which sometimes developed in these men, he attributed to this loss and the coincident excessive water intake. He was able to prevent cramp and fatigue associated with it by the administration of chloride.

${ }^{1}$ With the technical assistance of Etta Beer. 
The same year Weir (5) reported that the patients with diabetes insipidus he had studied did have a dilution of the blood which accounted for the slight reduction of plasma chloride.

In 1924 Greene and Rowntree (6) reported that they had also found in their experimental animals a definite dilution of blood as shown by reduction of serum protein, increase in plasma volume, and decrease in hemoglobin; but that the decrease in blood chloride often exceeded that expected from the degree of dilution. The possibility that this was due to loss of chloride by diuresis was ruled out as the decrease in blood chloride was quite as marked in the animals with oliguria or anuria as in those with the most marked diuresis.

Contrary findings were reported by Underhill and Sallick (7), who, while agreeing that the blood became diluted and that the magnitude of the blood chloride reduction exceeded the degree of hemodilution, claimed that a large amount of chloride was lost in the urine. They concluded that "the loss of tissue salts with consequent disturbance of the water-salt equilibrium of the body constitutes an important factor in the mechanism of water intoxication."

In 1927 Greene and Rowntree (8) confirmed their previous reports and added that "a trace of chlorides is present in the vomitus but this is inconsiderable by comparison with the changes in the body as a whole."

Misawa (9) using rabbits and the same experimental procedure as Rowntree demonstrated that in water intoxication there was a reduction of chloride in all the tissues of the body save the liver, as well as in the blood. The reduction was greatest in skeletal muscle where it amounted to a loss of 51 per cent and it averaged 20 per cent in other tissues, except in liver where a 10 per cent increase occurred. There was an increase in the water content of all tissues examined. This amounted to 2 per cent in brain, 4 per cent in muscle, and was highest, 5 per cent, in the liver. Misawa claimed that the concentration of chloride in the urine increased with the progress of the intoxication. Hemolysis and death appeared if water administration was continued after convulsions appeared. He considered that the symptoms of water intoxication were not due chiefly to water retention in the tissues or hydremia, but were much more dependent on the marked reduction of inorganic salts in the tissues and lowering of the molecular concentration of the serum.

Harding and Harris (10) have more recently repeated the experiments of Rowntree, particularly testing the effect of intravenous hypertonic urea solution, which they did not find of definite therapeutic value. They believe that the convulsive seizures of water intoxication occur when the retention of water has reached a critical value of 60 to $70 \mathrm{cc}$. per kilogram.

Clinically, McQuarrie (11) and Fay (12) have shown that epileptic convulsions are aggravated by the retention of water. McQuarrie (13) emphasizes particularly the changes in mineral balance which occur during the period of water retention in epileptics.

\section{EXPERIMENTAL PROCEDURES}

Our own experiments were started in August 1930. Dogs, which had not been fed after 11.00 A.M. of the previous day, were used. Distilled water was admi nistered by stomach tube at half hour intervals, in amounts varying from 20 to $75 \mathrm{cc}$. per kilogram of body weight. In the first experiments, however, 50 cc. per kilogram were used, as in Rowntree's procedure. An initial blood specimen was taken before the administration of water was started and a final specimen at the end of the experiment. Water administration was continued until definite toxic symptoms, and, in many cases, convulsions occurred. 
Occasionally this required only 3 to 4 hours, but with larger animals a 7 or 8 hour period usually elapsed before the convulsive state was reached.

The blood was taken from the external jugular vein. Part of the sample was discharged under oil with oxalate while with a second syringe blood was obtained without an anticoagulant for the sedimentation tube and fragility test, and serum for total base, protein and calcium. Hemoglobin and hematocrit measurements were made with blood obtained directly from the needle.

In the earlier experiments the urine and vomitus were collected and measured together as had been done by previous workers. In the later experiments these excreta were collected and analyzed separately.

In addition to the chemical studies, data on sedimentation, hemoglobin and red blood cell count and size have been collected. Fragility tests were also made in many experiments. At this time only observations on the chemical changes and their interpretation are presented.

The chemical methods used were the following: blood chloride, Van Slyke (14); blood sugar, Folin and $\mathrm{Wu}(15)$; nonprotein nitrogen, Folin and $\mathrm{Wu}(16)$; $\mathrm{CO}_{2}$ content, Van Slyke gasometric (17); $\mathrm{pH}$, Hastings and Sendroy bicolorimetric (18); inorganic phosphorus, Fiske and Subbarow (19); inorganic sulfates, Wakefield (20); urea, Leiboff (21); lactic acid, Friedemann (22); serum albumin and globulin, Greenberg's modification of Wu's method (23); total base, Stadie and Ross (24); urinary and gastric chlorides, Harvey (25).

\section{EXPERIMENTAL RESULTS}

The dogs, for the most part, mongrel or street types, varied considerably in clinical response. Some high-strung apprehensive animals (e.g. fox terriers) developed convulsions more readily than more staid types. In general, the younger and smaller dogs were more unstable. It was found that the animals which vomited early and frequently became toxic sooner, exhibiting at first tremors and ataxia, then prostration and convulsions. The effect of intravenous salt solution in allaying these symptoms was, in most instances, spectacular and practically immediate. In some experiments intravenous urea was tried but was without effect even when given for several days previous to the experiment as well as at the appearance of convulsions. The hemoglobin and hematocrit show more dilution of the blood after 20 to $26 \mathrm{cc}$. of water per kilogram every half hour (experiments 2 and 3, Table I) than after 75 cc. per kilogram every half hour (experiments 4 and 5, Table I). Even in the same animal and with the same dosage of water (experiments 4 and 5, Table I) the hemodilution is not the same. Although the blood dilution was greater, clinical manifestations were less marked and convulsions were provoked with more difficulty with the smaller amount of water. Weight increase, which has been stressed by Harding and Harris (10), is not a reliable index of the amount of water absorbed by the blood or body tissues. In experiment 2 (Table I) the weight change indicates a marked water retention, and hemoglobin and hematocrit a hemodilution, yet there is little clinical evidence of intoxication. In experiment 5 (Table I) with a marked increase in weight and little or no hemodilution, convulsions occurred. 


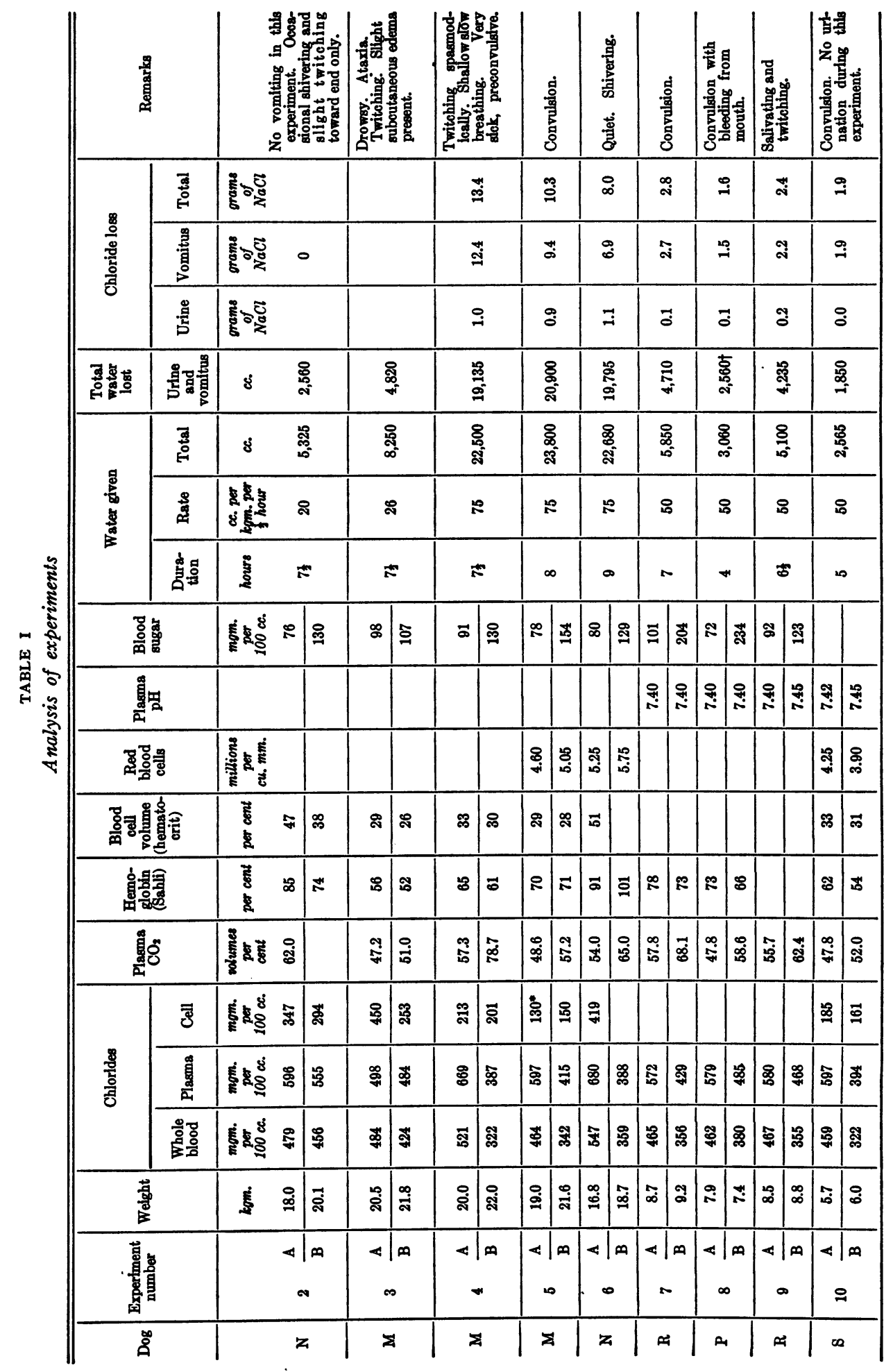


F. S. SMYTH, W. C. DEAMER AND N. K. PHATAK

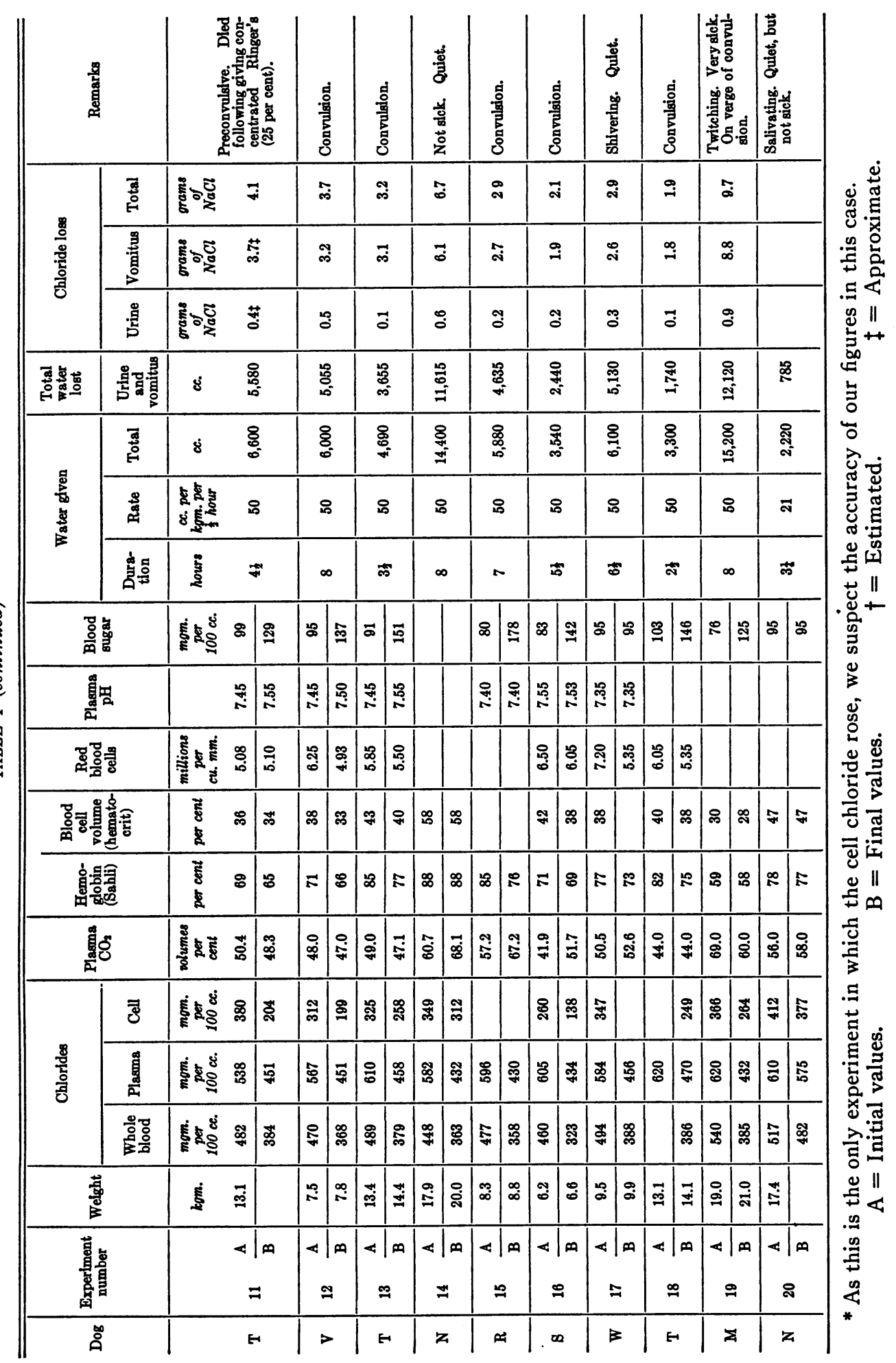


Obviously it would be misleading to assume hemodilution in the latter case from the increase in weight alone. From postmortem examinations, we are inclined to think that considerable water may be found in the gastro-intestinal tract, which, while increasing the weight of the animal, does not augment the water content of the body tissues or blood.

The most consistent change in all reports is the fall in blood chloride. From hematocrit, whole blood and plasma chloride determinations, the cell chloride content could be approximated. The average initial value for the latter was $335 \mathrm{mgm}$. $\mathrm{NaCl}$ per $100 \mathrm{cc}$. of cells, but determinations fluctuated from as high as $450 \mathrm{mgm}$. to as low as $185 \mathrm{mgm}$. In the same group the initial plasma chloride fluctuated from 680 to 498 with an average of 595. The change in cell volume is unrelated to the chloride loss, since the latter may be considerable when there is little change in hematocrit (experiments 11 and 14, Table I) and less marked when there has been quite a drop in cell volume (experiment 2, Table I). These findings are consistent with those of Gram (26), who found no evidence that the chloride concentration in the corpuscles rose or fell with the cell volume.

TABLE II

Experiment 1-50 cc. distilled water per kilo body weight every half hour from 10 A.M. to 4 P.M.

\begin{tabular}{|c|c|c|c|c|}
\hline Specimen & $\underset{\text { Sahli }}{\text { Hemoglobin }}$ & $\mathrm{CO}_{2}$ & $\begin{array}{l}\text { Whole blood } \\
\text { chlorides }\end{array}$ & Remarks \\
\hline & & $\begin{array}{l}\text { volumes } \\
\text { per cent }\end{array}$ & & \\
\hline I, 10 A.M.. & 59.5 & 53 & 433 & \\
\hline II, 1 P.M.. & 54.5 & 93 & 409 & $\begin{array}{l}\text { Vomited at } 11 \text { and } 12 . \text { Sali- } \\
\text { vating but not sick }\end{array}$ \\
\hline III, 4 P.M.. & 54.0 & 98 & 351 & $\begin{array}{l}\text { Vomited at } 1.30 \text {. Convul- } \\
\text { sion at } 4 \text { P.M. }\end{array}$ \\
\hline
\end{tabular}

Experiment 1 (Table II) represents one of the first experiments, which followed exactly the technique of Rowntree. It is cited here since the enormous increase in bicarbonate led us to suspect alkalosis and to study the loss of chloride more intensively. From what has already been said concerning the latter, it is not surprising that analysis of vomitus gives important information. While in individual animals time and amount of vomiting vary, there is none the less a definite correlation between the amount of chloride lost by vomiting and the reduction of chloride in the blood. In experiment 2 (Table I), where no vomiting occurred, the drop in whole blood chloride was less than in any other experiment; while in experiment 10 (Table I), where no urination occurred, the drop in chloride was large.

Rowntree (3) contends that "in dogs, vomiting unquestionably tends to postpone the onset of convulsions" and that in rabbits intoxication 
develops earlier because the water is practically all absorbed. Our findings, however, suggest that absorption of water is not so important a factor as loss of chloride, particularly by vomiting, and that vomiting therefore hastens rather than delays convulsions. As regards rabbits, Gamble (27) has shown that while these animals do not vomit, the stomach dilates and fills with chloride with effects quite comparable to those caused by removal of chloride from the body. In the light of Gamble's reports, Misawa's experiments (9), which were limited to rabbits and in which chloride was lowered in all tissues save liver, can easily be explained. We believe that a somewhat similar gastric retention without vomiting may have occurred in some of our experiments.

Considerable variation in the concentration of chloride in the vomitus can be noted in each of the experiments. In general, however, the chloride was more concentrated when the water was retained for longer periods. Hence infrequent vomiting might result in as much chloride loss as frequent vomiting of fluid with a lower chloride concentration. In some experiments on larger and more resistant animals, as vomiting continued for a long time, there also seemed to be a lessened gastric secretion. With regard to the urinary chloride excretion, our findings are at variance with those of Underhill and Sallick (7), and in agreement with those of Rowntree (3). The concentration and quantity of chloride in the urine rapidly fall. In fact, the loss by the kidneys usually fails to account for more than about one-tenth of the total loss. The loss by vomiting, which has been overlooked by previous investigators, accounts for the fall in blood chloride without the necessity of postulating any peculiar concentration of the ion in tissues.

This disappearance of urinary chloride associated with loss of chloride by vomiting is very similar to the findings of Hartmann and Smyth (28) in various types of vomiting in infants. Apparently when the level of blood chloride is reduced below a certain threshold little or no chloride is found in the urine. No such phenomenon is consistently encountered in the gastric secretion of chloride, though, as previously mentioned, some experiments show a reduction of gastric concentration toward the end of the experiment. Figure 2 illustrates by a typical example the changes in urine and vomitus.

In some additional experiments on atropinized animals which will probably be considered later, although there was considerable water retention, symptoms of intoxication did not develop, presumably because loss of gastric chloride was minimal.

The marked increase in plasma bicarbonate which was found in experiment 1 (Table II) led us to suspect alkalosis. The increase was encountered in most of the experiments. However, in some (experiments 11,12 and 13, Table I) there was a slight reduction. Rowntree found the plasma carbon dioxide capacity quite variable; the reduction of the alkali 


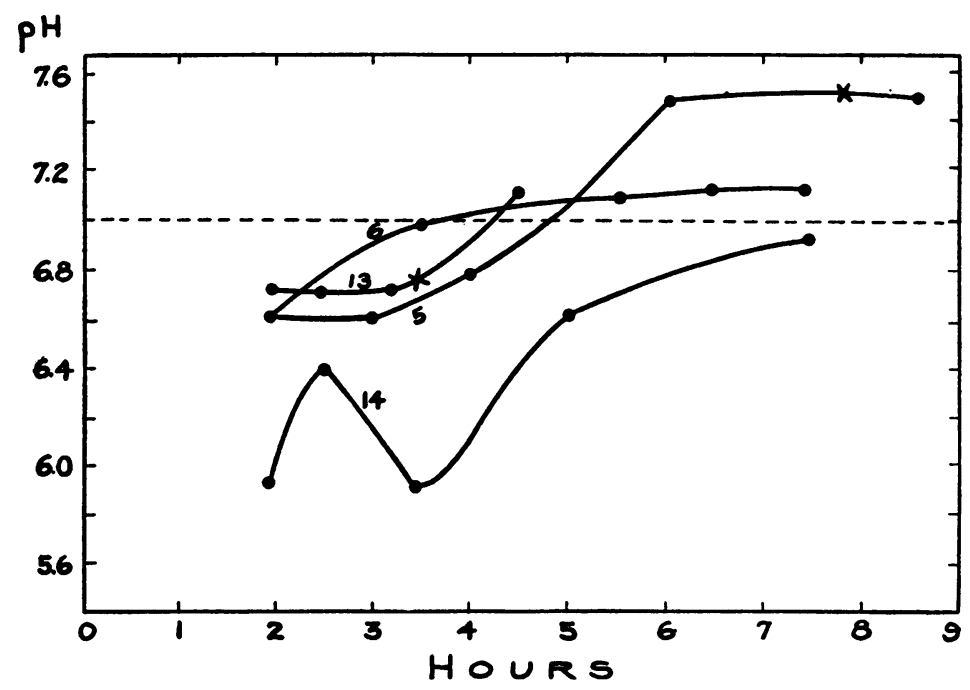

Fig. 1. Showing Change in Urinary pH During Experiment $\mathrm{X}=$ Convulsion. Figures on curves indicate experiment numbers.

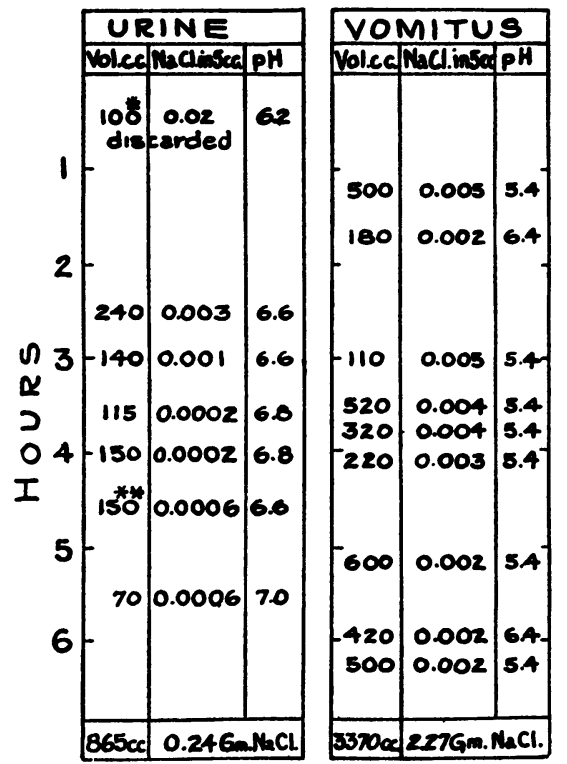

Fig. 2. Analysis of Urine and Vomitus in Protocol 9

* Discarded as urine in bladder before experiment began.

** Mixed with small amount of vomitus. 
reserve observed in some experiments he considered as indicating a loss of alkali.

That a different interpretation may be given was apparent when determinations of the hydrogen ion concentration were included. In experiments 11 and 13 (Table I), for example, the bicarbonate of the plasma dropped 2 volumes per cent. There was, however, a very definite increase in $\mathrm{pH}$. In experiments 9 and 10 (Table I) a similar increase was found though the bicarbonate was also increased. We feel that the general tendency is toward alkalosis. Where the bicarbonate is enormously increased, the $\mathrm{pH}$ may change little; but where the bicarbonate is not increased or is reduced, uncompensated alkalosis may be present with a definite change in $\mathrm{pH}$ before convulsions.

From a clinical standpoint we believe the shallow respiration which is usually present toward the end of the experiment is the typical breathing of alkalosis. The manipulation of the animal at the time of venupuncture in many instances upset the respiratory regulation and was perhaps responsible for the uncompensated alkalosis and convulsions. The convulsions themselves led to excessive production of lactic acid which to some extent modified the final result.

A study of the $\mathrm{pH}$ of urine and vomitus is likewise significant. The vomitus, as would be expected, remains acid. In some instances where the water did not remain long in the stomach the acidity was, of course, less marked. The $\mathrm{pH}$ of the urine, however, definitely increased after the fall in chloride concentration (Figure 1). In experiments 5, 6 and 14 (Figure 1) this is apparent. In experiment 13, which represents a rapid development of intoxication, the $\mathrm{pH}$ of the urine did not change until after the administration of saline, when it shifted strongly to the alkaline side, $\mathrm{pH} 7.0$ to 7.2. In other words, the excess base of bicarbonate was released when chloride deficiency no longer obtained. Sodium chloride supplied base, which had probably been depleted, as well as chloride. The latter replaced bicarbonate, which was in excess, and sodium bicarbonate was excreted.

The determinations of total base were unsatisfactory, but the second specimen of serum uniformly showed loss of total base. In experiment 13 the reduction was considerable. In this instance also the urine $\mathrm{pH}$ did not change until after the therapeutic administration of saline. That vomitus may contain varying amounts of duodenal base is probable. No attempt was made to estimate this. In some instances, however, the presence of biliary pigment in the vomitus was obvious, and we are inclined to suspect the fall in total base to be largely dependent on the loss of duodenal contents in the vomitus.

With regard to other determinations our findings are similar to those of Rowntree. Early experiments included the estimation of diffusible calcium by Greenberg's method (23), but neither this fraction nor the 
total calcium was appreciably changed. Urea and nonprotein nitrogen determinations were omitted from most experiments for the same reason. We had earlier expected that to maintain osmotic pressure non-electrolytes would rise to compensate for the electrolyte reduction. The rise in sugar which did occur was associated only with convulsions. The rise in lactic acid, which also depended on convulsions, was relatively greater than that of sugar. That lactic acid may affect the plasma bicarbonate and play a beneficial role in counteracting alkalosis has already been mentioned.

\section{CONCLUSIONS}

Neither water retention in the body nor hemodilution is the most essential feature of so-called experimental water intoxication. The convulsive symptoms are more closely associated with loss of chloride by way of gastric secretion and a resulting alkalosis.

The relative influences of water absorption, chloride loss, and alkalosis have been distinguished by studying the effects of administering varying amounts of water.

There is little evidence that non-electrolytes increase in the blood to compensate osmotically the electrolyte depletion.

\section{BIBLIOGRAPHY}

1. Miller, J. L., and Williams, J. L., Am. J. M. Sc., 1921, clxi, 327. The Effect on Blood Pressure and the Nonprotein Nitrogen in the Blood of Excessive Fluid Intake.

2. Weir, J. F., Larson, E. E., and Rowntree, L. G., Arch. Int. Med., 1922, xxix, 306. Studies in Diabetes Insipidus, Water Balance and Water Intoxication. Study I.

3. Rowntree, L. G., Arch. Int. Med., 1923, xxxii, 157. Water Intoxication.

J. Pharmacol. and Exper. Therap., 1926, xxix, 135. The Effects on Mammals of the Administration of Excessive Quantities of Water.

4. Moss, K. N., Proc. Roy. Soc., London, Series B, 1923-1924, xcv, 181. Some Effects of High Air Temperature and Muscular Exertion upon Colliers.

5. Weir, J. F., Arch. Int. Med., 1923, xxxii, 617. Observations on the Influence of Pituitary Extract on the Metabolism in Diabetes Insipidus.

6. Greene, C. H., and Rowntree, L. G., Am. J. Physiol., 1924, lxviii, 111. Changes in Concentration of the Blood Following the Administration of Excessive Quantities of Water.

7. Underhill, F. P., and Sallick, M. A., J. Biol. Chem., 1925, lxiii, 61. On the Mechanism of Water Intoxication.

8. Greene, C. H., and Rowntree, L. G., Am. J. Physiol., 1927, 1xxx, 209. The Effect of the Experimental Administration of Excessive Amounts of Water. I. On the Volume and Concentration of the Blood.

Am. J. Physiol., 1927, 1xxx, 230. The Effect of the Administration of Excessive Amounts of Water on Body Temperature.

9. Misawa, H., Japanese J. M. Sc. Tr., Sec. VIII, Internal Medicine, Pediatry and Psychiatry, 1927, i, 355. Über das Wesen der sogenannten Wasserintoxikation. 
10. Harding, V. J., and Harris, L. J., Tr. Roy. Soc., Canada (Sect. V, Biol. Sc.), 1930, xxiv, 101. Urea Administration in Water Intoxication.

11. McQuarrie, I., Am. J. Dis. Child., 1929, xxxviii, 451. Epilepsy in Children: the Relationship of Water Balance to the Occurrence of Seizures.

12. Fay, T., Am. J. Psychiat., 1929, n.s. viii, 783. Some Factors in the "Mechanical Theory of Epilepsy" with Especial Reference to the Influence of Fluid and Its Control in the Treatment of Certain Cases.

13. McQuarrie, I., Manchester, R. C., and Husted, C., Am. J. Dis. Child., 1932, xliii, 1519. Study of the Water and Mineral Balances in Epileptic Children. I. Effects of Diuresis, Catharsis, Phenobarbital Therapy and Water Storage.

14. Van Slyke, D. D., J. Biol. Chem., 1923, lviii, 523. The Determination of Chlorides in Blood and Tissues.

15. Folin, O., and Wu, H., J. Biol. Chem., 1920, xli, 367. A System of Blood Analysis. Supplement I. A Simplified and Improved Method for Determination of Sugar.

16. Folin, O., and Wu, H., J. Biol. Chem., 1919, xxxviii, 106. A System of Blood Analysis. Supplement I. A Simplified and Improved Method for Determination of Sugar.

17. Van Slyke, D. D., and Cullen, G. E., J. Biol. Chem., 1917, xxx, 289. Studies of Acidosis. I. The Bicarbonate Concentration of the Blood Plasma; Its Significance and Its Determination as a Measure of Acidosis.

18. Hastings, A. B., and Sendroy, J., Jr., J. Biol. Chem., 1924, lxi, 695. Studies of Acidosis. XX. The Colorimetric Determination of Blood pH at Body Temperature without Buffer Standards.

19. Fiske, C. H., and Subbarow, Y., J. Biol. Chem., 1925, lxvi, 375. The Colorimetric Determination of Phosphorus.

20. Wakefield, E. G., J. Biol. Chem., 1929, lxxxi, 713. The Colorimetric Determination of Total and Inorganic Sulfates in Blood Serum, Urine, and Other Body Fluids.

21. Leiboff, S. L., and Kahn, B. S., J. Biol. Chem., 1929, lxxxiii, 347. A Rapid and Accurate Method for the Determination of Urea in Blood.

22. Friedemann, T. E., Cotonio, M., and Shaffer, P. A., J. Biol. Chem., 1927, lxxiii, 335. The Determination of Lactic Acid.

23. Greenberg, D. M., J. Biol. Chem., 1929, Ixxxii, 545. The Colorimetric Determination of the Serum Proteins.

24. Stadie, W. C., and Ross, E. C., J. Biol. Chem., 1925, lxv, 735. A Micro Method for the Determination of Base in Blood and Serum and Other Biological Materials.

25. Harvey, S. C., Arch. Int. Med., 1910, vi, 12. The Quantitative Determination of the Chlorids in the Urine.

26. Gram, H. C., J. Biol. Chem., 1924, 1xi, 337. Chlorides of Serum, Blood and Corpuscles in Various Pathological Conditions.

27. Gamble, J. L., and McIver, M. A., J. Clin. Invest., 1925, i, 531. A Study of the Effects of Pyloric Obstruction in Rabbits.

28. Hartmann, A. F., and Smyth, F. S., Am. J. Dis. Child., 1926, xxxii, 1. Chemical Changes in the Body Occurring as the Result of Vomiting. 